\title{
Towards a humanising pedagogy: an autoethnographic reflection of my emerging postgraduate research supervision practice
}

\section{Suriamurthee Maistry}

\begin{abstract}
Postgraduate supervision in South Africa is a fraught academic space. The ASSAF Report (2010) indicates that supervisor competence is a key contributing factor in student attrition. The coupling of autonomous student and competent supervisor is far from being the usual pattern in South African higher education. Furthermore, postgraduate supervision workshops and courses seldom focus on how particular practices are likely to result in social exclusion, giving far more attention to technical aspects of supervision. This paper considers instead the unwitting 'othering' that has occurred in my history as a supervisor and gives an account of ideas and principles that have guided me in seeking to improve my own practice. I focus in particular on those elements or aspects of my practice that are likely to (or do) alienate and marginalise my postgraduate students as I engage with supervising their work. My paper records an ongoing exercise in self-reflexion, shaped methodologically by the tenets of critical autoethnography, as a means to examine potentially subjugating effects that I can identify in my practice as supervisor with a diversity of postgraduate students. In this paper I reflect on two important aspects of supervision: verbal critique and written critique. I probe these two aspects with a view to altering my own trajectory of development in the direction of a more productive level of self-awareness in my practice. I argue that a sustained, careful and considered approach to student supervision that understands and conceptualises writing as a process (rather than a product) has enormous potential for facilitating and developing student academic writing competence. A heightened sensitivity to the debilitating and demeaning effects of careless feedback commentary and embracing research supervision as humanising pedagogy have significant implications for helping students to negotiate the liminal space in which they must master the threshold competences needed for success in advanced higher education research.
\end{abstract}

\section{Introduction}

The aim of this paper is to provide a reflexive account of my induction into the world of research supervision. I attempt to probe my ideological 
orientation by examining how, in its genesis, it came to influence my supervisory practice. I draw inspiration from Grant's application of Hegel's master-slave trope in the analysis of relations of power in the supervision encounter (Grant, 2008), reflecting on the way it can potentially enable me to develop heightened self-awareness as supervisor. I begin with a brief sketch of emerging issues, locally, and in the literature, which outlines the chief imperatives that frame my work as supervisor of graduate students. In keeping with the spirit of autoethnographic research, I present a set of relational ideas rather than a conventional set of research findings and recommendations.

The University of KwaZulu-Natal has declared its ambition to be a 'research-led' institution. The attainment of this vision depends on the institution's potential to expand its $\mathrm{PhD}$ programmes and the capacity of its academic personnel to service these programmes. Historically, the minimum requirement to supervise PhD students in the UKZN School of Education has been a $\mathrm{PhD}$ qualification. A PhD was thus the required 'license' to supervise $\mathrm{PhD}$ studies; attainment of a $\mathrm{PhD}$ was the right of passage by which an academic became entitled to supervise the knowledge creation process at doctoral level. This is a somewhat myopic perspective as it presumes that mere acquisition of a $\mathrm{PhD}$ automatically signifies command of the complex set of competences needed for successful PhD supervision. To its credit, UKZN does offer a formal postgraduate supervision course that is compulsory for new and junior colleagues as part of its Postgraduate Diploma in Higher Education. This course covers a range of competences which includes developing familiarity with internal research policy, processes and procedural issues, going from research proposal development through to thesis examination. A question still to be answered is the extent to which this kind of generic postgraduate supervision course can address, in an appropriately nuanced manner, the notion of research supervision as a humanising pedagogy (Khene, 2014).

Drawing on insights from Paulo Freire, Khene (2014) puts forward the notion of a humanising pedagogy for supervisory practice in developing contexts. In a context such as South Africa, where higher education institutions enrol students with widely varying levels of preparedness for advanced $\mathrm{PhD}$ study, research supervision envisaged as a humanising pedagogy can potentially redirect the focus of supervision so that it centres on the development of the $\mathrm{PhD}$ student rather than on the ultimate product (the thesis report). This potentially progressive move appears, however, to be under threat, as higher education institutions increasingly shape their policies to conform with a 
neoliberal agenda centred on competitive participation in the knowledge economy (Adkins, 2007). While the notion of postgraduate supervision as pedagogy (Clegg, 2014) has gained currency in recent years, evolving scholarship in this field has begun to indicate a need for more nuanced approaches to supervision that go beyond the traditional Oxford model (Burford, 2014; Grant, 2014; Wisker, Robinson and Schacham, 2007).

The post-apartheid agenda for higher education in South Africa has been shaped by a host of policy documents and reports that have emerged over the past two decades from the Centre for Higher Education Transformation, the Council on Higher Education and the Centre for Research on Science and Technology and the Academy of Science in South Africa (ASSAF). Recent developments and pronouncements emanating from the National Policy Commission (2011) and the National Development Plan indicate a strongly neoliberal knowledge-economy agenda for higher education in South Africa. This can be seen in the projected target outputs for $\mathrm{PhDs}$, envisaged to increase from the current 1500 per annum to 5000 per annum by 2030 (National Development Plan, 2012). While the ASSAF report also signals the importance of strengthening the $\mathrm{PhD}$ profile of the country, it highlights institutional factors that need consideration if this agenda is to be fulfilled (ASSAF, 2010). An issue of particular concern is that the entities which are expected to deliver on this, namely the higher education academic fraternity in South Africa, which is severely under-capacitated in regard to PhD-qualified personnel (less than $35 \%$ of all academics). To build capacity, a target of 75 per cent academic staff with $\mathrm{PhD}$ qualifications is envisaged. This presents as a somewhat bizarre and cryptic mathematical formula which suggests that the existing 35 per cent who have PhDs should in the next 15 years supervise and graduate both the academic colleagues needing to be brought up to $\mathrm{PhD}$ level to make up the 40 per cent shortfall of adequately qualified staff and supervise the additional 3500 per year of new PhD students needed by the national economy. Very clearly, the postgraduate supervision context in South Africa is a highly fraught academic space.

National higher education policy and targets translate into ambitious institutional plans that have already seen a significant rise in new $\mathrm{PhD}$ enrolments. Whether there is sufficient capacity and competence to give effect to these grand plans is another matter. In South African higher education it can by no means be assumed that an 'always/already' autonomous student (Manathunga and Gozee, 2007) will automatically be matched with a competent supervisor, and the ASSAF Report (2010) indicates that supervisor 
competence is now a key contributing factor in student attrition. Furthermore, postgraduate supervision workshops and courses invariably focus on technical policy and on the procedural and administrative aspects of supervision (liberal pre-occupations), seldom considering the likelihood that one or another supervisory practice is likely to result in social exclusion. To disrupt this canon, Manathunga (2009) urges that we should

\begin{abstract}
explore how in supervision, we as supervisors engage both in compassionate, teaching strategies that guide and support our students' learning and in providing rigorous and challenging feedback ... where supervisors must act as both the student's mentor and supporter and, at the same time, the gatekeeper of the discipline ... to discuss, debate and re-think both the cognitive and administrative aspects of supervision practice as well as the emotional and irrational and the unconscious political dimensions (pp.343-344).
\end{abstract}

At the same time, Firth and Martens (2008) caution that there must also be an appropriate balance between the emotional and the rational elements of supervisory practice

The work of a graduate supervisor is clearly a complex undertaking in which 'risks and pleasures' (Grant, 2003) abound. In the remainder of this paper, I revisit some of the paths by which I have sought to arrive at a heightened self-awareness of how I conduct myself in my role as supervisor in this enterprise, and in negotiating the inherent power dynamics which are at play.

\title{
A brief methodological note
}

Autoethnography as a methodological approach in academic research has gained significant currency in recent years and its credentials as a mode of research are now well established (Ellis, Adams and Bochner, 2011). Its maturity as a research tradition is signalled by its multiplying variants, such as analytical autoethnography (Denzin, 2006) and critical autoethnography (Boylorn and Orbe, 2014), to name just two. Critical autoethnography has particular appeal for me as it appropriates the tenets of critical theory and autoethnography in a way that gives me a critical frame for exploring my embedded and implicated self-in-practice (Boylorn and Orbe, 2014). My personal narratives are presented here not as any kind of cathartic confessional but in an authentic attempt at candid self-exposure of my supervisory practice. I attempt to probe my pedagogy, invoking the notion of a 'poor pedagogy' (Masschelein, 2010) as a means to unveil relations of power at work in my supervisory encounters with my students. In particular, 
Foucault's inspiration, cited (in translation) by Masschelein (2010), that this be accomplished through a process of self-exposure; a self-induced vulnerability and a concomitant disposition of attention, presence and generosity as I engage a reciprocal, formative learning encounter with my graduate students.

In particular, I attempt to understand the dominant discourse that shapes my ideological orientation in research supervision with a view to disrupting and deconstructing hegemonic practices in which I have become complicit.

Critical autoethnography allows me to apprehend ambiguity and contradiction as necessary conditions inherited from the hierarchical normative constructions of the supervision enterprise in higher education.

Autoethnography is a means by which I can unravel the haecceity, the essence of me in my practice. I take heed of Manathunga's call for supervisors to "engage with a language and ways of thinking and being that enable them to critically and reflexively investigate their supervision practices" (2009, p.345). This, I attempt to do through a process of deep reflexion; through thoughtful, extended, calm yet intense cogitation and profound consideration and contemplation of my practice. I must concede though that it has been a real struggle to give effect to the reflexive project, as reflexion is a high-level competence that is likely to create cognitive dissonance; a traumatic unsettling as one confronts the notion of 'educating the gaze' (Masschelein, 2010). Learning reflexion is in essence a meta-cognitive process, imbued with a temporality that is determined by the extent of one's disposition to critical introspection.

\section{Unravelling my own socialisation as writer and research supervisor - a narrative vignette}

One implicit objective of this paper is to encourage modalities of research reporting that challenge the conventional canon - specifically, the modality of presenting a relational set of ideas rather than a report of 'findings' from analysed data.

I begin, accordingly, with an attempt to expose my own socialisation into reading and writing - tracing back my early experiences in an attempt to uncover the genesis of my ideas and my identity as reader and writer. Without venturing on a full-blown genealogy in the Foucauldian sense, I draw 
inspiration from Foucault in seeking to understand how my current identity has come to be, with a view to its disruption and dissolution. What set of 'accidents' and discontinuities produced my identity? Implicit in this powerful line of Foucauldian thought is the suggestion that rather than being trapped by our histories we have the potential to actively shape them (Feder, 2011).

The socioeconomic circumstances of my upbringing, especially during my primary school years, shaped my early attitude towards reading and writing in particular ways. In my own home, there was little to inspire a love for writing let alone the development of any fine writing skill. Neither of my parents (children of first-generation indentured labourers) nor my older brother had progressed beyond primary school education, and my older sister dropped out at Grade 9 to seek employment so that she could help support our family. My family thus struggled with their own challenges in reading and writing. Being read to, or reading for family, were never a feature of our day-to-day life. The only reading material to be found would be the odd comic book (discarded by neighbours) and from time to time a school-issue reader, which I read only if my teachers told me to (and they seldom did). At the state-aided Indian primary school that I attended, homework, in those days, did not really come into the picture. And although the medium of instruction was English, the English language curriculum seldom went much beyond technical points of grammar and punctuation. In English classes, we did what was called 'Composition and Letter, in a special exercise book for this purpose, on mostly random, decontextualised topics such as 'A day at the beach' or 'My holiday on the farm', neither of which I could relate to, living in an inland city and never having set foot on a farm. Actual composing of text was not a skill that anyone gave any real attention to. If a written piece was free of grammatical and punctuation errors, that was quite enough to earn commendation. My high school reading and writing career was for the most part similarly stunted, with much the same emphasis in the writing curriculum. In my undergraduate degree, I majored in commercial subjects, where sophisticated writing skills were certainly not a priority; much more important was the manipulation of figures and graphs.

In the nine years that I subsequently spent as a school teacher of commercial subjects, I focused exclusively on the content of the discipline; it never occurred to me that teaching my students how to read and write might also be one of my responsibilities. In the first few years of my career as a university academic involved in undergraduate teacher education (commercial subjects), 
my exclusive focus was again on the content of the disciplinary field that I taught, with only limited consciousness of how students gained access, through reading and writing, to the discourse of the disciplines I taught.

I was fortunate (or perhaps not so) to have completed my Master's and $\mathrm{PhD}$ in Education with a professor who possessed remarkable English language proficiency skills. He meticulously corrected each of my written submissions using the Track Changes function in Microsoft Word - which I duly accepted without contestation. The supervision model was the one-on-one supervision relationship: strong, powerful supervisor and subservient student.

With my $\mathrm{PhD}$ completed, it would be fair to assume that I might by this stage have developed some level of competency in academic writing, but as student I had not developed a level of academic maturity that made me consciously aware, at that time, of the learning-to-write that was taking place, nor, importantly, how this might influence the way I went about helping my own postgraduate students to 'learn'. In other words, I had not paid any particular attention to the supervision pedagogy being used or to my own thinking about how I was learning. I had not, in other words, developed a meta-cognitive awareness of my learning.

Nevertheless, successful completion of a PhD in the UKZN School of Education was a virtually automatic license to supervise Master's and even $\mathrm{PhD}$ students in cases where staff supervisory capacity did not exist. Because I was the only academic with a PhD in Economic Education, almost all Master's and $\mathrm{PhD}$ students wanting to research in the broad field of commerce education were directed to me by default. My supervision workload was well beyond the School norm (a circumstance that also fed my growing ego - a point on which I have more to say later in this paper).

Looking explicitly for ways to enhance my supervision skills, my next step was to join the School of Education $\mathrm{PhD}$ cohort supervision programme which was being conducted under the leadership of a group of experienced supervisors.

\section{Lured by a liberal discourse: cognition - not emotion!}

The PhD cohort supervision model that took root in the newly merged University of KwaZulu-Natal in 2004/5 was a model inherited from the 
former University of Durban-Westville. The history of this cohort-seminarbased model has been documented by Samuel and Vithal (2011: 85), who note that "the pedagogy of research teaching and learning evolved into a mature doctoral cohort model within UKZN. . . (with) emergent philosophies of democracy, scaffolding, Ubuntu and serendipity as useful pillars. ..". The programme had become known as a robust academic space, led by a core group of accomplished and powerful academics committed to increasing the quantity and quality of PhDs. As a forum, it had a reputation for strong critique (of PhD student work), with a developmental nuance, and could point to a string of graduates who had profited from the three-year cohort experience. A culture of frank, candid, open and direct critique was a distinguishing feature of the programme, in which there was much emphasis on structure, timelines, the supervisor-student 'contract', timely submissions and a goal-oriented focus as prescribed by the then Faculty of Education's policy on higher degrees research. Govender and Dhunpath (2011), in what they describe as an exploratory study of this $\mathrm{PhD}$ cohort programme, comment on the extent to which $\mathrm{PhD}$ students learn both within and outside of the cohort community of practice, and, in a subsequent publication (Govender and Dhunpath, 2013), they highlight the need for the programme to cultivate academic maturity and student autonomy in the post-proposal defence stage.

All three of the well-documented interpretive studies which I have just cited of this particular PhD cohort programme were framed by liberal humanist approaches to research supervision (with its assumption of human autonomy and rationality) - a framing that unwittingly masks the subtleties and the subtext of the supervision enterprise. As such, the subtle and sometimes overt 'violences' that occur are 'overlooked' or outside the focus of such studies (Grant, 2003). There appeared to be a relative insensitivity to the fragmentary, splintered, and historically conditioned nature of the human subject in the research learning space. In contrast, post-liberal research on supervisory practices "seeks to problematise language, subjectivity, power and identity in ways that emphasise the fragmented, partial and multiple nature of the self" (Manathunga, 2009, p.344).

Aside from some anecdotal disgruntlement (somewhat casually alluded to by the researchers cited above) on the part of a few academics affected by the deliberations at cohort sessions, there was relative silence about the 'regimes of truth' (Foucault, 1979) being engendered with regard to supervisory practice at work in this space. As I have already noted, the defining feature of 
this $\mathrm{PhD}$ cohort programme was the high-level, strong, robust critique that students came to expect in the forum. It is important to emphasise that in a high-level academic space of this order critique is a 'natural' necessity. Where tension can arise, however, is in the manner in which critique is provided or dispensed to the student. In this respect there appeared to be minimum concern for the affective domain or the individual subjectivities of students who were in turn shaped by biography, race, class, language, gender and ethnicity. Students were assumed to all have the same degree of resilience to withstand incisive critique and the same capacity to comprehend this critique, particularly in the first two years of the programme where student levels of academic maturity may have been low. While supervisors did remind novice $\mathrm{PhD}$ students that the critique was not meant to be taken personally, there certainly were instances when critique degenerated into judgmental commentary about students' cognitive abilities. In my notes after the very first $\mathrm{PhD}$ cohort supervision session of 2008 with a novice group of PhD students, I mused over how several students were 'cut down to size' by the experienced supervisors. The power of these supervisors was indeed appealing; a power that I began to aspire towards. A comment regularly uttered to students without due consideration for how it would be received and interpreted (especially to students who had not adequately conceptualised their studies) was the rather blunt and abrasive "This is not a PhD, what makes your study a $P h D$ ?" Students who in several cases occupied powerful positions in their own professional work contexts were unwittingly and sometimes deliberately constructed as deficit, as not knowing, and while this $\mathrm{PhD}$ cohort had become renowned as a vigorous research learning space, it also developed a degree of notoriety. Resilient students endure, but not enough is known about how the less resilient, the more sensitive, and the not 'always/already' autonomous student responds in such learning contexts (Manathunga and Gozee, 2007, p. 309).

Of particular importance for me, though, is my own uncritical assimilation into the discourse and practice of the programme, a willing learning by apprenticeship of observation (Lortie, 1975), in which I actively participated. As a new $\mathrm{PhD}$ graduate and relatively young supervisor I explicitly set out to learn whatever I could about research supervision through my connection with this PhD cohort programme. Not having come through a PhD cohort supervision programme myself, I was initially in awe of the level of engagement that took place and the commentary that emanated from the experienced supervisors. In my notes over 2008 and 2009, I have recorded instances where students' presentations (written and oral) were systematically 
dismantled to reveal its inadequacies (and strengths in some instances). Over the three years, I uncritically assimilated the style of supervision. What I significantly failed to discern at the time was the unwitting violence meted out to $\mathrm{PhD}$ students in each session. I also began to find my 'critical voice' actively participating in the unrestrained critique, flagrantly oblivious to the power that came with my position, gender, race and language. As such, I had scant regard for student biography, personal context or history, believing that these were peripheral to the 'pure' research issue that I was critiquing. In my second three-year cycle, I co-led a cohort of novice $\mathrm{PhD}$ students. I revelled in the power, eager to uphold the historically established 'standard': namely, that the PhD cohort programme was a demanding space, not for the faint-hearted. As I became more adept (as I thought) at providing critique (sometimes even treading dangerously in fields of study outside my area of expertise), it fuelled my growing ego. I was intent on developing and establishing a 'reputation' for being critical - which often just meant being dogmatic, insistent and unapologetic - blissfully unaware of the harm caused by my 'friendly fire', which is what it amounted to. The students, in effect, fell victim to my poorly directed attack on the misconceived 'enemy': the academic or research issue ostensibly under debate. Some might indeed say that 'friendly fire' is an inevitable risk in a combat engagement where outcome outweighs costs. For my part, I had adopted and internalised this potentially injurious ideological disposition and was now actively promoting a hegemonic discursive practice. There were moments when I positively relished the discomfort I created, especially when the students on the receiving end were themselves in positions of authority in their own right (and who sometimes carried assumptions of authority into $\mathrm{PhD}$ cohort sessions). An example of such a moment was when a new $\mathrm{PhD}$ student, (a principal at a school) reflected on the many accomplishments at the school since her appointment and the amazing relationship that she enjoyed with her staff. Her intention was to study her practice. My own response was not to acknowledge this but to offer a cutting and personal attack on the student with the following unwarranted comment: "You appear to be over-glorifying your practice when you should be troubling it. So does anyone on your staff think you're doing a crap job?"

In Lacanian terms, I was experiencing a jouissance (Zizek, 2008) - a momentary (and questionable) surfeit of enjoyment and pleasure. I was walking a slippery, contradictory line, especially since my self-declared paradigmatic preference has been Critical Theory. In essence then, I was not 'living' the critical project. 
As a 'natural' consequence, I began to carry this relish in discomforting students through to my engagement with my PhD students' writing. When I reflect on the feedback I provided to students on their written submissions (of which I have kept electronic records), the stark, over-zealous, aggressive, and 'loud' commentary is plainly evident, resembling a kind of 'bleeding' (as one student put it) in the ruptures inflicted by my red 'tracked changes' and overabundant comment boxes. Typical commentary on students' written submissions included:

What is this?????

You appear to be confused!

This is unacceptable at this PhD level!!!

A very cryptic sentence - what is the reader supposed to make of this???

Unclear????

Rephrase!!!

This is a poorly constructed sentence!!!

Not sounding right!

This is rather incoherent!!!!

I was particularly impatient and intolerant of grammatical, punctuation and syntax 'errors', which often caused me to lose sight of the idea and meaning that my students were trying to present. Subsequent reflection leads me to see this as a reaction to my own insecurities as a novice supervisor and my own inadequacies as a writer and a teacher of high-level academic writing. A particular turning point was my exposure to post-liberal literature on the research supervision enterprise which I had begun to engage with as a result of my involvement with the Strengthening Postgraduate Supervision Programme' (SPS) funded by the Netherlands Organisation for International Co-operation in Higher Education. It allowed me to reflect on how I had misguidedly attempted to project (or mimic) a competent and confident demeanour, with scant awareness of how this demeanour was being received by my students. I tended to come on too strongly and aggressively at initial supervisory sessions, often 'over-speaking' about issues and concepts and over-elaborating on the elevated cognitive competences expected at $\mathrm{PhD}$ level, much of which was foreign to my novice research students. A critical 
incident was my engagement with one of the key themes in the SPS programme, namely, that of 'social exclusionary research supervision practices in higher education in South Africa'. This triggered a recognition of how I had in the past, made only the feeblest efforts to affirm the knowledge base of these high-calibre degree candidates, being more occupied with belabouring the 'enormous' gaps in their disciplinary educational research knowledge. Such pontifications usually happened at one-on-one supervision sessions with insensitive deficit constructions of my students as reflected in comments such as: "Because you lack an educational research background, you have to work even harder, so what will you give up in your busy life to take on this high-level PhD study". This was a typical brusque and crude utterance that constructed students as 'lacking' and unable to manage their personal lives. Much of this positioning was done in an attempt to assert myself and gain the student's confidence in my ability, thereby exhibiting my own need for recognition and acknowledgement. In my current practice, I do far more careful and attentive listening and constant self-reminding of how the construction of my feedback might be received and interpreted by my students.

In the next part of my discussion, I shall try to analyse the relations of power that might be discerned in the uneasy self-portrait I have just offered.

\section{Towards a Hegelian self-awareness}

In applying a Foucauldian notion of power as relational, one would argue that subjects are never in a permanent state of subjugation: subjectivity is in fact continuously shaped in and through power relations. In constructing subjectivity, individuals (in the present instance, supervisor and student) are always working within a context of constraint. At the same time, individuals are nonetheless essentially 'free' to act and react, although navigating relations of power should not be taken to imply that one can completely extricate oneself from the power relations that prevail. There will always be an element of uncertainty as to whether actions and reactions will re-create new relations of power or reinforce those that already exist. However, every 'localised episode' has potential to significantly disrupt and it is never certain which point of contestation or which discursive event will create a rupture (Foucault, 1979, p.27). In the supervision encounter, both supervisor and student are accordingly 'free' to act and react. Like Grant (2008), I contend, 
however, that curtailing the analysis at this point leaves us somewhat hamstrung - which was also the feeling I had when, in another paper (forthcoming 2015), I applied a Foucauldian framework to an analysis of neo-liberal managerialism in higher education. The assumption that students may have the capacity, the confidence and the constitution to give effect to their inherent 'freedom' is slightly problematic since it dilutes the effect of 'structural asymmetries' on subjects in the interaction (Grant, 2008, p. 11). In attempting to now make sense of the power dynamic in the supervision encounter, I draw on Grant's post-critical work in which she uses Hegel's master-slave trope to analyse inherent hierarchical power relations in postgraduate supervision (Grant, 2008). She argues that the master-slave archetype allows us to discern why it may well be necessary for research supervisors to engage the ambiguity that comes from the trope being "both disturbing and productive for supervision" (B. Grant, 2008, p. 10). She argues that it is entirely plausible that a hierarchical bond could exist between a knowledgeable supervisor (an institutionally determined disciplinary 'expert' in her field, vetted by the academic fraternity) and the new postgraduate student (being inducted into the field) and that it may be naïve to assume that both subjects can engage at the same level. In the relationship between the supervisor (master) and student (slave), two kinds of self-consciousness are at work. Each subject's self-consciousness is possible only when she is aware of the other's awareness of herself - when one is able, in other words, to see oneself through the eyes of the other and when there is a mutual recognition of the tension that arises as consequence of one another's otherness. When these two self-awarenesses engage, there is potential for the creation of a new self-awareness for both subjects. Applied to the supervisory encounter, Grant suggests that there is a mutuality (of struggle and dependence) that exists between supervisor and student and that this is mediated by the production of the thesis - a dialectical relationship in which they interact interdependently. She acknowledges that although the master-slave trope may well be repugnant as a template for understanding the supervisory practice, it serves nonetheless as a powerful reminder "that supervision is not a free space but one productively, disturbingly too, structured by larger forces" (B. Grant, 2008, p.25).

What, then, are the implications of the analysis I have presented for my ongoing supervision practice. 


\section{Discussion and concluding comments}

How do I best move to an appropriate level of self-awareness? Some of the preceding exposition could well signal a modest move towards selfawareness. But while absolute self-consciousness is elusive, I want to argue that one can nonetheless aspire towards a deliberative, meta-cognitive sensitivity to the way one is invested and implicated in the supervisory encounter. To reach this point necessarily requires a kind of attentiveness; one has to desire "a state of mind which opens up to the world in such a way that the world can present itself to me (that I can 'come' to see) and I can be transformed ... a space of possible self-transformation or self-displacement" (Masschelein, 2010, p.44). Such a space for possibility may well be attained when we probe our pedagogy, or consider a "poor pedagogy" that may encourage us to explore attentively "practices which allow us to expose ourselves" (Masschelein, 2010, p.44). Of particular significance for me is Foucault's contention, cited (in translation) by Masschelein, "that critique starts with attention, presence and generosity" (Masschelein, 2010, p.48). These are particularly germane points of aspiration that might convey me to a higher level of self-awareness, to a level where I can see myself from the perspective of my students and nurture in myself a compassionate empathy for my students' endeavours to navigate new intellectual terrain. Kamler and Thomson remind us that "the novice researcher enters what we call occupied territory - with all the imminent danger that this metaphor implies - including possible ambushes, barbed wire fences, and unknown academics who patrol the boundaries of the already occupied territories" (Kamler and Thomson, 2008, p.29). Over-zealous, condescending and dispassionate supervisors (like myself) are likely to compound this challenge. A nuanced understanding and recognition of this is thus important if I wish to create an enabling research learning space.

My new awareness of myself in my supervision practice falls well short of an epiphany. Rather, it has been a combination of factors working in concert over a period of time that has triggered the revelation of 'me' in my own eyes and ' $m e$ ' in the eyes of others. I have been fortunate to have worked in a range of research teaching and learning spaces (seminars, cohort supervision sessions, co-supervision sessions) with colleagues at the university who have commented critically on my style and approach to supervision. Their critique was initially not always well received by me, especially during my 'ego trip' phase. Thinking back, a material trigger was the look of despair that I began 
to notice on the faces of my various students when they were on the receiving end of the caustic, abrasive, stinging critique that I chose to deliver. Another telling trend was the reluctance of some students to make and honour supervision appointments or submit draft versions for discussion. A more overt indicator of my self-alienation was the reluctance of colleagues to nominate me as examiner of their students' work, either in formal assessment of postgraduate proposals (which entailed an oral defence) or for completed theses. This was an unsettling period for me, with a good deal of angst, since critical introspection and self-diagnosis were not my strong suites. My more recent exposure to post-liberal literature, coupled with readings on teaching writing as process and on the power of formative feedback, has certainly helped me rethink my approach to both my students and my colleagues. With students' writing, I have become more aware of the need to focus on the ideas and arguments being constructed, and I am learning to resist the temptation to correct technical aspects of language. I also remember to give praise and affirmation where they are due.

Arguably the most significant 'adjustment' in my approach has been a heightened appreciation of the need to create enabling conditions for intellectual development of the human subjects I am privileged to work with, rather than being doggedly focused on ultimate delivery of the technical product (the thesis). I now understand better than before that doctoral study is both text work and identity work, that doctoral students develop their own identities through textual construction (Kamler and Thomson, 2008). It is still early days to draw any conclusions about the effect that my shifted perspective might be having on my students and colleagues. I have, however, learnt that deep introspection can be traumatic. It has created a kind of dissonance in me that has been quite disconcerting. My learning curve continues to be particularly steep and I do have lapses where I default to my old ways - which, thankfully, seems to be happening less and less frequently.

All said, I do not choose to offer 'recommendations' (about a humanising pedagogy) such as one might expect in a conventional research paper. Perhaps the paper then falls short of expectations when read against its title. But what I do hope is that this reflective account will find resonance with fellow supervisors, both veterans and novices, and that they may find benefit in a raised self-awareness of their presence in the supervisory encounter. Contemplation of a humanising pedagogy has been my learning path in the endeavour to be more human in the supervisory encounter. Although I have, since 2008, seen through to completion, the work of ten Master's graduates 
(two cum laude) and four $\mathrm{PhD}$ graduates, I continue to ponder the "collateral damage' I may have inflicted in the process. I am however mindful of Grant's insights that self-awareness develops through a process of mutual recognition and struggle.

Foucault's insights continue to be a source of inspiration for me.

\section{References}

Adkins, B. 2007. PhD pedagogy and the changing knowledge landscapes of universities. Higher Education Research and Development, 28(2): pp.165-177.

ASSAF. 2010. The PhD Study. Pretoria.

Boylorn, R.M. and Orbe, M.P. 2014. Critical autoethnography: intersecting cultural identities in everyday life. California: Left Coast Press.

Burford, J. 2014. Doctoral writing as affective practice: keep calm and carry on. In Bitzer, E., Albertyn, R., Frick, L., Grant, B. and Kelly, F. (Eds), Pushing boundaries in postgraduate supervision. Stellenbosch: SUN Press, pp.69-84.

Clegg, S. 2014. Knowledge questions and doctoral education. In Bitzer, E., Albertyn, R., Frick, L., Grant, B. and Kelly, F. (Eds), Pushing boundaries in postgraduate supervision. Stellenbosch: SUN Press, pp.11-24.

Denzin, N.K. 2006. Analytical autothnography, or Deja Vu all over again. Journal of Contemporary Ethnography, 35: pp.419-428.

Ellis, C., Adams, T.E. and Bochner, A.P. 2011. Autoethnography: an overview. Forum: Qualitative Social Research, 12(1).

Feder, E.K. 2011. Power/knowledge. In Taylor, D. (Ed.), Michel Foucault: key concepts. Durham: Acumen Publishing Limited, pp.55-70. 
Firth, A. and Martens, E. 2008. Transforming supervisors? A critique of post-liberal approaches to research supervision. Teaching in Higher Education, 13(3): pp.279-289.

Foucault, M. 1979. Discipline and punish: birth of prisons, (S. S. A. M., Trans.). New York: Vintage.

Govender, K. and Dhunpath, R. 2011. Student experiences of the PhD cohort model: working within or outside communities of practice. Perspectives in Education, 29(3): pp.88-99.

Govender, K. and Dhunpath, R. 2013. Harmony and conflict in a PhD cohort supervision model. Alternation, 9: pp.219-247.

Grant, B. 2003. Mapping the pleasures and risks of supervision. Discourse: Studies in Cultural Politics of Education, 24(2): pp.175-190.

Grant, B. 2008. Agnostic struggle: master-slave dialogues in humanities supervision. Arts and Humanities in Higher Education, 7(1): pp.9-27.

Grant, C. 2014. Pushing the boundaries of postgrauate supervision: theorising research learning in community. In Bitzer, E., Albertyn, R., Frick, L., Grant, B. and Kelly, F. (Eds), Pushing boundaries in postgraduate supervision. Stellenbosch: SUN Press, pp.109-122.

Kamler, B. and Thomson, P. 2008. The failure of dissertation advice books: towards alternative pedagogies for doctoral writing. Educational Researcher, 37(8): pp.507-514.

Khene, C.P. 2014. Supporting a humanizing pedagogy in the supervision relationship and process: a reflection in a developing country. International Journal of Doctoral Studies, 9: pp.73-83.

Lortie, D.C. 1975. Schoolteacher: a sociological study. Chicago: University of Chicago Press.

Manathunga, C. 2009. Supervision as a contested space: a response. Teaching in Higher Education, 14(3): pp.341-345. 
Manathunga, C. and Gozee, J. 2007. Challenging the dual assumption of the 'alway/already' autonomous student and effective supervisor. Teaching in Higher Education, 12(3): pp.309-322.

Masschelein, J. 2010. E-ducating the gaze: the idea of a poor pedagogy. Ethics and Education, 5(1): pp.43-53.

Samuel, M.A. and Vithal, R. 2011. Emergent frameworks of research teaching and learning in a cohort-based doctoral programme. Perspectives in Education, 29(3): pp.76-87.

Wisker, G., Robinson, G. and Schacham, M. 2007. Postgraduate research success: communities of practice involving cohorts, gaurdian supervisors and online communities. Innovations in Education and Teaching International, 44(3): pp.301-320.

Zizek, S. 2008. The plague of fantasies. London: Verso.

Suriamurthee Maistry

School of Education

University of KwaZulu-Natal

maistrys@ukzn.ac.za 